\title{
Spreading the evolutionary synthesis: Theodosius Dobzhansky and genetics in Brazil
}

\author{
Aldo Mellender de Araújo \\ Universidade Federal do Rio Grande do Sul, Instituto Latino-Americano de Estudos Avançados, \\ Instituto de Biociências e Grupo Interdisciplinar em Filosofia e História das Ciências, \\ Departamento de Genética, Porto Alegre, RS, Brazil.
}

\begin{abstract}
The so-called Evolutionary Synthesis, the present paradigm for evolutionary explanations, was established during the 1920s, 1930s and 1940s. One of the leading scientists contributing to this was Theodosius Dobzhansky, a Russian born geneticist who emigrated to the United States of America in 1927 to study with Thomas Hunt Morgan. He was also responsible for the development of Drosophila genetics in Brazil, which was the main organism employed in experimental studies of evolution. Dobzhansky had several opportunities to visit Brazil starting in 1943, to do field and laboratory work as well as teaching. All these activities were fundamental in the spreading of new concepts, methodology, and objectives of the Synthesis to a new audience. This paper discusses the results of the interaction between Dobzhansky and a group of young Brazilian researchers, particularly from the University of São Paulo.
\end{abstract}

Key words: evolutionary synthesis, Brazilian genetics, Dobzhansky, Drosophila genetics.

Received: March 19, 2003; Accepted: March 8, 2004.

\section{Introduction}

The so-called Evolutionary Synthesis, or simply the Synthesis, was a scientific movement started in the 1920s and consolidated in the 1940s. It was based primarily on the amalgamation of Mendelian genetics and Darwinian evolution, which tried to keep a common denominator among other groups, for zoologists, paleontologists, geneticists, and botanists. A vast number of articles and books were already written about the synthesis; two outstanding contributions are those by Mayr and Provine $(1980,1998)$ and Smocovitis $(1992,1996)$. Mayr and Provine's book has the subtitle "Perspectives on the Unification of Biology", while Smocovitis' book is entitled, Unifying Biology; they both wanted to stress that the Synthesis was imagined as a unifier of all biology, perhaps as part of a desired unification of all sciences. Although Mayr and Provine's book attempts to give an overview of the development of the Synthesis in

This paper is dedicated to Daisy Lara de Oliveira (1958-1999), beloved friend and colleague of the Interdisciplinary Group in Philosophy and History of Sciences, UFRGS, Brazil.

Send correspondence to Aldo Mellender de Araújo. Universidade Federal do Rio Grande do Sul, Departamento de Genética, Caixa Postal 15053, 91501-970 Porto Alegre, RS, Brazil. E-mail: aldomel@portoweb.com.br. different European countries, the one by Smocovitis is mainly concerned with Anglo-American contribution. This later approach was criticized by Reif et al. (2000) as being an example of the "hardening" in historiographic studies of the Synthesis; their paper deals with the German contribution to the Synthesis.

The present communication is divided into two parts. The first attempts were to summarize, chronologically, the main papers and books accepted as the background for the establishment of the Synthesis. In the second part I try to address questions concerning Dobzhansky's stay in Brazil, specifically around the year 1943. What kind of genetics was done before Dobzhansky's arrival? What expectations had the Brazilians about the visit of such an important personality? What was his main contribution to the development of evolutionary genetics in Brazil? What evolution was taught in Brazilian universities at the time and what kind of research was there on the subject?

\section{The beginnings of the Evolutionary Synthesis}

In what follows, I will try simply to enumerate and discuss briefly the main events leading to the synthesis. After the "eclipse of Darwinism" , the year 1918 appears as its revival particularly with Ronald Fisher's paper on "The

1 This epithet was employed by Julian Huxley in his book Evolution - The Modern Synthesis (1943; p. 22); the historian of science Peter Bowler used it as a title of one of his books (1983). 
correlation between relatives on the supposition of Mendelian inheritance". There he managed to explain Mendelian genetics and quantitative variation by the same principles. In 1922 he published "On the dominance ratio", where he examined not only the conditions for a stable equilibrium under selection in a one locus two allele situation, but also the survival of individual genes in the case of no-selection. He also discussed what he called "the Hagedoorn effect", which would be later called random genetic drift. For the Hagedoorn effect he reached the conclusion that the decay in genetic variance would be proportional to $1 / 4 n(n=$ population size), a result later disputed and corrected by Sewall Wright.

The year 1922 was marked by an important paper by Wright, "Coefficients of inbreeding and relationship", where a quantitative measure of inbreeding was proposed (based on the decrease in heterozygosity) and whose meaning was important for his shifting balance theory of evolution. In the years 1924-1926 J.B.S. Haldane published the first three papers (out of nine) on natural selection, in a series entitled "A mathematical theory of natural and artificial selection". His treatment of the consequences of natural selection in the case of simple models (one locus, two alleles) used the ratio between gene frequencies, as Fisher did before him. It is interesting to note that what we see now in standard population genetics textbooks, when dealing with simple modes of selection, represents only small modifications of the content of the first of Haldane's papers.

The 1930 decade is often cited as the decade of the Synthesis; it starts with the publication, in 1930, of Fisher's book The Genetical Theory of Natural Selection, one of the classics of the foundations of the synthesis. Chapter II introduces the famous "fundamental theorem of natural selection", which states that "the rate of increase in fitness of any organism at any time is equal to its genetic variance in fitness at that time" (p. 37, second revised edition, 1958). This theorem proved to be a very useful tool for thinking in the evolution of natural populations, although its demonstration and applicability are still debated (incidentally, Dobzhansky never cited this theorem in the three editions of his Genetics and the Origin of Species; it appears only in 1970 in his entirely new book Genetics of the Evolutionary Process). Following Fisher, Wright published his long and fundamental article "Evolution in Mendelian populations" in 1931 (a summary had been published in 1929). Here is an attempt to analyze the effects, in isolation or combined, of mutation, migration, selection and genetic drift. In that same year he presented a talk at the Sixth International Congress of Genetics, in Ithaca, N.Y. about "The roles of mutation, inbreeding, crossbreeding, and selection in evolution" which would be published the following year. This "was probably the most influential paper he ever published", said William Provine as editor and commentator of Wright's works on evolution (1986). Dobzhansky attended the congress and became deeply impressed by Wright's presentation; one of the pictures shown there was popularized, so to say, in Dobzhansky's 1937 book.

The Causes of Evolution by J.B.S. Haldane appeared in 1932; the book focused on four general questions: (a) are differences between species of the same nature as differences between individuals of the same species? (b) How does natural selection work and what is its importance in evolution? (c) Given that evolution can also occur in a nonadaptive way, how can this be reconciled with the action of natural selection? (d) How to reconcile the conflicting evolutionary interests of gametes, individuals, and populations? The book also includes an Appendix dealing with the mathematical theory of natural selection.

We come now to Dobzhansky's contribution to the early synthesis: his 1937 book Genetics and the Origin of Species, considered a cornerstone in the establishment of the synthesis. The book had three editions (1937, 1941 and 1951), with remarkable differences in the first and last ones. Dobzhansky's originality was also expressed in his series of papers (I to XLIII) called "Genetics of natural populations", from 1938 until 1976 (the last paper was published posthumously). The salient features of all these publications were the use of the experimental method to test hypotheses about the mechanisms of evolution acting on natural populations, supported by a strong theoretical design, usually inspired by Sewall Wright (for a comprehensive analysis of this interaction see Provine 1986a).

This short list of leading papers and books contributing to the evolutionary synthesis can be concluded with Ernst Mayr's 1942 book Systematics and the Origin of Species and George Gaylord Simpson's Tempo and Mode in Evolution (1944). They represent the contribution to the synthesis of those external to the genetics circle, respectively, zoologists and paleontologists (botany came later, with G. Leddyard Stebbins' 1950 book Variation and Evolution in Plants). All the above references are those usually cited and accepted as the most influential to the synthesis (there are many others which deserve serious attention, including those "expurgated" from the synthesis). It would be very interesting to discuss other population ecology and evolution papers, in the 1920s and 1930s, that were neglected in the development of the synthesis; however, this is not the aim of this paper.

\section{Brazilian genetics and evolution in the early 20th century and Dobzhansky's role in their development}

The beginnings of genetics in Brazil can be traced back to 1918 , since already at that time the subject was taught in a school of agriculture, called Escola Superior de Agricultura Luiz de Queiroz. This school attained a good reputation in the following years and is still a high quality center in quantitative genetics and plant breeding. There, 
Carlos Teixeira Mendes taught genetics and expressed his ideas about this subject as well as about evolution, showing an influence from De Vries in his texts (which perhaps was not unusual at the time). That school maintained a bimonthly journal, Revista de Agricultura, which frequently published articles or short papers dealing with genetics and evolution. These were in great part comments or translations of papers published abroad, but Brazilian geneticists also presented original research articles. For instance, in 1933 Carlos Krug published a series of five papers about the genetics and improvement of corn, with substantial original data. He had been at Cornell University the year before where he had the opportunity to attend the Sixth International Congress of Genetics as the only Brazilian representative (Krug, 1932). One personality from Escola de Agricultura Luiz de Queiroz who became particularly well-known in Brazil for his unorthodox view of gene function was Salvador de Toledo Piza Jr., who in 1930 published a book expressing the view that genes would not exist as corpuscular units; instead, the whole chromosome would be the unit of heredity. This brought him close to some of Richard Goldschmidt's ideas.

By the mid-1930s, Piracicaba and Campinas-both towns in the state of São Paulo - were the centers where studies in genetics took place. At Piracicaba, Friedrich Brieger, a recently arrived German cytogeneticist, started studies on the evolution of orchids and also taught genetics. At Campinas, Carlos Krug who had moved from Piracicaba, taught genetics and started research on the genetics of coffee, which later brought to the Instituto Agronômico de Campinas an international reputation. Around 1940 they independently wrote papers on genetics and evolution, showing that they were acquainted with the available literature (Krug, 1940; Brieger, 1944). A name deeply important in this historical survey is that of André Dreyfus, not because he was a prominent researcher in genetics but instead, as a teacher of genetics and embryology since 1919 in Rio de Janeiro and from 1934 as the head of the Department of Biology in the newly founded University of São Paulo. He was a self-taught scholar and discussed genetics in conferences and articles, maintaining that a conciliation between evolutionary theory and genetics would be desirable for an understanding of the mechanisms of evolution, although he attributed a principal role to mutations (Dreyfus, 1934). Moreover, he was the one who made the contact with Harry Miller Jr. from the Rockefeller Foundation to bring Dobzhansky to Brazil; he organized a team of young researchers and students who helped Dobzhansky in all field work in 1943 and also translated his conferences so they could be read in Portuguese by a diligent Dobzhansky! (Brito da Cunha, interview on Oct. 20/1998). About Dreyfus, Dobzhansky wrote, in a letter to Demerec (July 8, 1943):

"First of all, I do hope that there will be some Drosophila work in Brazil after I return to USA.
Dreyfus is a very good man, and although he is now busy part of the time with his new work as the dean of the Faculty, both he and at least two other people in his laboratory are I think sufficiently seriously interested to do the job. Dreyfus has been invited by our State Department to visit USA, so we are likely to see him in December and January in New York. He, I repeat, is a very good and personally a charming man, and he has some nice work to report besides."

Indeed he had some nice work to report. For instance, in 1937 he presented a dissertation about sex determination in Rhabdias fulleborni, a parasitic nematoid of some Amphibia. Only females were known then and two hypotheses were advanced: parthenogenesis or, instead, the occurrence of very small males which died soon after fertilization. Dreyfus' work showed that none of these hypotheses were true; females of Rhabdias fulleborni were in fact hermaphrodites, the male gonads occurring inside the ovaries; he studied the anatomy of the gonads as well as the spermatogenesis, ovogenesis and fertilization of this animal (Vaz, 1966). Dreyfus also worked with sex determination in hymenoptera and, under Dobzhansky's influence, chromosomal mutations and sexual isolation in species of Drosophila.

Thus, although genetics in Brazil was concentrated mainly in the state of São Paulo, its implications for agriculture and medicine, and its connections with evolutionary biology were not unknown to Brazilians. It is fair to say that by the mid 1940s genetics was on its way to becoming an institutionalized scientific discipline in Brazil. People from other states in the country have also contributed to genetics, particularly human genetics, since 1925 . In this context, the contribution by a physician called Jessé Accioly is remarkable. A native of the state of Bahia, he published a long paper where he discussed sickle cell anemia as a monogenic inherited disease in the Arquivos da Universidade da Bahia in 1947. This was done independently of James V. Neel from the USA, who published in that same year his classic about the inheritance of this genetic disease (Beiguelman, 1980). In a place as distant as Belém, the capital of the state of Pará in the Amazonian region, José Maria Hesketh Condurú, a teacher in the agricultural and veterinary school, published a two-volume book entitled $A B C d a$ Genética (The ABC's of Genetics) in 1934. It was a pretty clear text on variability, Mendelian principles, biometry, selection and evolutionary theories. In the thirties, after the creation of the Universidade de São Paulo (1934), the first in Brazil to have people working full-time, there was

"a true experience of a scientific and cultural Renaissance which affected greatly the entire intellectuality of the country" (Pavan and Brito da Cunha, unpublished manuscript). 
As two contemporaries of these times, these authors later declared:

\begin{abstract}
"When Dobzhansky was for the first time invited to come to Brazil (1943), the country's academic environment was mature enough, at least, to eagerly receive all the contribution he was willing to give" (Pavan and Brito da Cunha, 2003).
\end{abstract}

These two statements must be taken with some caution: it is true that the emergence of the University of São Paulo in 1934 greatly modified scientific research in Brazil. That was due mainly because, as occurred in other fields for each key position in the biological sciences (traditionally zoology and botany), a European or USA scientist was invited to head a group and to start research. These investigations, however important, were not devoted to evolutionary questions; instead, they dealt with taxonomic descriptions or were concentrated in the physiology of certain groups of animals and plants. As for paleontology, it had an old tradition in Brazil, although decoupled from evolution until the mid-40s. It is interesting to note that an examination of three important papers on the history of zoology, botany and paleontology in Brazil, written by scholars from the University of São Paulo, did not mention Dobzhansky's visit to Brazil in 1943, nor that he could have stimulated studies in evolution in those respective fields (Ferri, 1980; Narchi, 1980; Mendes, 1981). These facts seem to stress the hegemonic influence of genetics in evolutionary studies and, particularly in the development of a theory of evolution in the 1930s and 40s. On the other hand, the common statement that before the foundation of the University of São Paulo there was no scientific research in Brazil is being increasingly criticized (see, for instance, Marinho 2001).

The beginning of the interaction between Dobzhansky and the Brazilian geneticists started when Harry Miller Jr., representing the Rockefeller Foundation "made his first trip below the Caribbean in 1941 on a prospecting tour of the South American universities, looking for opportunities to assist teaching and research in the natural sciences" (Glick, 1994; see also Schwartzman 1979; Marinho 2001).

What occurred later was an arrangement to bring Dobzhansky to Brazil to teach and start research in genetics as a substitute for Dreyfus, who could then stay in the USA during the same time (actually Dreyfus went to that country only the following year). As Dobzhansky was applying for a grant to the Rockefeller Foundation to study tropical Drosophila populations in Central America, he was told that Brazil could provide the same opportunity. On November 24, 1942, he wrote to Miller explaining his plan for the study of natural populations. He said that nothing was known of population structure in the tropics, and that it was important to find out the mutation rates of tropical species, as well as migration rates. On January 26, 1943 he wrote a letter to Sewall Wright:
"A few days ago all my plans have undergone a radical change, or rather my plans are now what I have tried to make them for more than a year. It seems as though I am being sent to Brazil for six months (April-September), four months to teach genetics to Brazilians at São Paulo, and two months to chase flies somewhere in Amazonas. [...] Now, I have been yearning to discuss the plans of this Brazilian venture with you for God knows how long a time. I still yearn to do so, but it is so damnably difficult to do in letters. [...] This Brazilian venture is, of course, a plan the execution of which would take a number of years. I think there is a possibility of much to be gained by studying the population structure in species living in a climate that changes as little as possible during the year. [...] Grand plan all right, with a lot of ifs and ands and buts, but its success will to a certain extent depend upon starting early, until one is still capable of starting such long time project. I think not more needs to be said - you can see yourself how useful would be to go over the parts of the Grand Plan with you."

In his reminiscences for the Oral History of Columbia University (1962) he said:

"...in collaborating with Wright I have, of course, been very excited about this problem of genetic drift. [...] Now, one of the important variables there, or so it seemed to me at that time, is that in temperate climates, where you have summer and winter seasons, the populations of many animals, including Drosophila, pass every year through a series of contractions and expansions. The flies hibernate almost certainly as adults, and during the winter season most of them die out, so that by spring only a few survive, presumably chiefly impregnated females, also some males are left, and they start the ball rolling from the beginning. As the season progresses, and more fruits and other food is available, the population grows very large. It is this periodic reduction of the population to small size which seemed important as a possible agency bringing about this genetic drift. That led to a very simple idea: if the genetic drift is due to seasonal alternations, chiefly winter resulting in destruction of the flies, then what would happen in a tropical climate where winter never comes? There season after season the population should be large enough to eliminate genetic drift. [...] Now, I just as well say at this point that this proved to be wrong. It proved to be wrong because although there are no winter-summer seasons in the tropics, seasonal changes are by no means absent." 
Dobzhansky was very busy after his arrival; the following day he was collecting flies around the city of São Paulo with three other people among whom was Crodowaldo Pavan, a young Brazilian biologist that became close to Dobzhansky in the years to come and that later was an influential geneticist in his own country. In a letter to Milislav Demerec from April, 1943 Dobzhansky tells him about his activities in the new environment:

"It is only a little more than a month since I have left New York and not quite three weeks since my arrival in São Paulo. [...] I had and am having a splendid time and am enjoying myself thoroughly. [...] After some unavoidable waste of time contingent on starting the work in a new place (time which has been filled with social preoccupations with new acquaintances), I have started my work too. Have by now some 10-15 species of Drosophila, and undoubtedly many more to come since some are represented so far by single females and other, not included in the above count, were represented by single males. My attempts to find out their names with the aid of the Texas book has been on the whole futile.[...] It looks as though the commonest species in the jungle here is Drosophila willistoni, but damned if I can run it to willistoni in Sturtevants key! Anyway, I think I shall be working some during the years to come with a little, almost diminutive, yellowish beast having three pairs of chromosomes - two V's and a rod."

Later that year he wrote a long letter to Sewall Wright, from Belém do Pará, right in the Amazon forest. There he described the difficulties of studying Drosophila in the tropics as well as some bizarre adaptations to be explained by natural selection:

"I have spent in São Paulo even five months, and these five months were pleased almost to a minute. The work has been mostly in the laboratory, although eight excursions have been made including one to Rio de Janeiro; [...] As far as Drosophila is concerned, we (that is my collaborator Pavan and myself) have studied only those species which we were able to breed and to examine all the stages. [...] Here in Belem the work has just been begun (it is not yet two weeks since I came here); the number of species is as expected very large but it is most difficult to collect and to breed them. The amount of natural food is evidently so great that Drosophilas are not just interested in the bait offered to them, and the Drosophila culture technique of the usual kind has not been made for the Amazonian climate, and most species just plain die. [...] Aside from doing Drosophila I have been just looking at the tropical nature, observing things at large, and trying to store these observations and impressions for thinking them over at leisure. Tropical forest is an environment so different from ours of the temperate zones that all biological conceptions or preconceptions with which a 'temperate' biologist starts have to be critically examined. [...] Many things seem just absurd for natural selection to permit; take for example the sloth - an animal devoid of either active or passive defense, what right has such a thing to exist? Or a tree which when it reaches a certain size looses its solid trunk and is transformed into a kind of lacework, the wood in this lace being to be sure extremely hard. Such examples can be multiplied manifold." (September 28, 1943)

Back to New York he wrote again to Sewall Wright asking advice to decide with what species would be more profitable to investigate population structure in the tropics. He said that he had been able to cultivate a dozen species of Drosophila from Brazil and that there were a lot of problems to be studied, although he had no assistants or graduate students to do the job. The choice of the "target" species was indeed a difficult decision to make, as can be seen from this passage:

"Choosing the species is a difficult job, and I would dearly love to have an opportunity to discuss it with you. There are several species that breed well and, consequently, are eligible. [...] D. willistoni or related to it, is very good as a laboratory animal (develops faster than $D$. melanogaster!). It is however very common everywhere in Brazil, and to that extent not a 'typical' species. Now, it would seem interesting to know something about the population structure in a common tropical species, but on the other hand a 'typical' case is more interesting. Should $\mathrm{I}$, then work on willistoni, or would some other moderately common species be preferable? What is your opinion?" (November 15, 1943)

The response to the above letter was given two weeks later, and to Dobzhansky's discontent Wright was of no help simply suggesting that it would be desirable for comparative purposes to work with three species: a rare, a 'typical', and a common one.

As the title of this communication suggests, the travel to Brazil was an opportunity to spread those ideas and concepts that were part of the emerging synthesis. This can be appreciated in the following quotation from an unpublished manuscript by Pavan and Brito da Cunha on "Dobzhansky's role in genetics in São Paulo":

"In the original agreement it was stated that he would, besides collecting flies, give a few lec- 
tures for students and faculty members, but this was changed to a special course on Principles of Evolution which was assiduously attended by over 100 people, many of them faculty members of different schools and research institutions, students and people of liberal professions, newspapermen as well as biologists from cities close to São Paulo." (p. 3)

Of course, it would be extremely interesting to know who suggested the referred to changes. What could be better than to teach a new audience that finally biology had achieved unification? How wonderful it would be to tell young students that whatever their background, paleontologists, zoologists, botanists and others could finally agree regarding the mechanisms of evolution? Perhaps even better would be to introduce to a selected group of persons the power of experimental population genetics as the key to understanding evolution in action. Dobzhansky was a master of the experimental methodology as applied to natural populations. As Will Provine said, the Genetics of Natural Population series, which he had started a few years before, "despite whatever limitations, opened a whole new approach to the study of evolution that has been so widely accepted that it now appears to be common sense." (summary of remarks prepared for the International Dobzhansky Symposium, Leningrad September 17-19, 1990).

Dobzhansky's teaching was based on the second edition (1941) of his book Genetics and the Origin of Species and was developed in 15 lectures over two months. In July of that year (from the $20^{\text {th }}$ to $25^{\text {th }}$ ) he participated as a special guest in a meeting of genetics organized by the already cited Escola Superior de Agricultura Luiz de Queiroz at Piracicaba, São Paulo. The meeting was organized in two modules: one long session in the morning to discuss relevant subjects; and a session of communications in the afternoon. He was in charge of coordinating two discussions, one dealing with the problem of heterosis and the other about the species concept; he also gave a conference entitled "The gene as a self-reproducing unit in cell physiology" on the closing day of the meeting.

The text he prepared for the discussion on heterosis stressed the importance of studying natural populations and this was illustrated by his findings in Drosophila pseudoobscura. On the other hand, the relevance of population genetics to a general theory of heterosis was explicitly stated in several passages:

"Intercrossing of inbred strains produces an increase in vigor ("hybrid vigor" or heterosis), because deleterious recessives become covered up by favorable dominants. Studies on the genetics of natural populations of Drosophila pseudoobscura support the above theory, in so far as they show that most individuals indeed carry deleterious recessives in heterozygous con- dition. At the same time, these studies permit formulations of a more general theory of heterosis."

Such a general theory, as he explained, would depend on the population structure of the species, for which three typical cases could be predicted: (1) species where selffertilization is the only or the predominant method of reproduction, or species with very low effective population size; for these species, detrimental mutants are promptly eliminated by natural selection and inbreeding produces no loss of vigor and outbreeding no or very little heterosis. (2) Species with intermediate or moderately large effective population sizes; deleterious mutants would accumulate in natural populations and heterosis from crossing inbred strains would be more or less pronounced. (3) Species with very large effective population sizes; deleterious recessives would accumulate to the full extent determined by their mutation rates. In such cases heterosis would be most pronounced, since many genes in the homozygote condition would be removed by natural selection which tends to keep the heterozygotes' adaptive value.

In his talk previous to the discussion about the species concept he emphasized reproductive isolation as the main factor for the establishment of different species. He also stressed that "laboratory experiments furnish valuable information for distinguishing species, but the results of laboratory experiments must be very carefully evaluated against the natural conditions to prevent misinterpretation" ( $p$. 442). The emphasis on reproductive isolation had been already recognized as valid by Mayr in his 1942 book, although there he criticized Dobzhansky's definition of species saying that "this is an excellent description of the process of speciation, but not a species definition" (p. 119). Moreover, he insisted that the criterion of crossability "is not applicable to the isolated forms, and these are the really important ones" (p. 120). Dobzhansky was perfectly aware of this limitation when he wrote for the discussion: "the difficulties are frequently encountered where populations residing in different territories (allopatric) are involved" (p. 442). It is curious that Dobzhasky did not try to define species in this paper, nor does he mention any contributor to that definition. I think this is not devoid of interest, since in the paper about heterosis he did so, as well as in his conference on 'the gene as a self-reproducing unit in cell physiology". Why did he not mention Mayr's biological species concept at all?

Dobzhansky went back to the United States in October of that year. The "Brazilian venture" as he once said was by all measures successful. He brought to Columbia University some tropical species of Drosophila to work with; he left in Brazil a group of dedicated followers that helped to spread his teaching and way of working (perhaps even of thinking). Finally, he left the door open for a new visit, which effectively occurred in 1948, then again in 1952 and 1955 (other trips, for a couple of days or a week, 
also occurred at different times until 1966). This research program, started in 1943, was Dobzhansky's main project outside the United States over the next 15 years (Pavan and Brito da Cunha, unp. man.).

The success of this first visit to Brazil can be measured by the number of papers published, still in 1943, dealing with the genetics and taxonomy of Brazilian species of Drosophila. Three papers were published; one with André Dreyfus, and another with Crodowaldo Pavan, dealing with chromosome variability in some species, which were published in the Proceedings of the National Academy of Sciences (USA). The third, also with Pavan, was a long monograph describing 31 species of Drosophila, (23 of them new!), which appeared in a Bulletin of the University of São Paulo. In the year following, he published two more articles on Brazilian species, one co-authored with Ernst Mayr (the only paper they published together), dealing with sexual isolation in Drosophila willistoni, the other with G. Streisinger about geographic strains of $D$. prosaltans. Furthermore, in 1944, a monograph of more than 100 pages was published, in Portuguese, on the mechanisms of evolution and the origin of species; this was translated by one of his Brazilian assistants, Rosina de Barros. His Brazilian team was also active: in the intervening years from 1944 to 1948 they published 6 more articles. Crodowaldo Pavan, his favorite Brazilian disciple, spent one and half years at Columbia University (Jan. 45-Aug. 46). The financial support for all these activities came from the Rockefeller Foundation, which continued until late in the fifties.

Although this communication was restricted mainly to the results of the first of Dobzhansky's trips to Brazil (elsewhere I discuss some general questions- Araújo 1998; 2001), I think it is worth concluding with some of his 1962 recollections from the Oral History of Columbia University:

"Now, I have been many times of course asking myself, was it a good idea or not to spend as much as three years there. Was it or was it not a good time investment? I suppose that has to be answered in two parts. It certainly was an excellent time investment, as far as the genetic research is concerned, my own research. Although it was a sort of misapprehension which made me originally go there, certainly enough results were obtained that the time was well spent. The other aspect is, helping to start genetics, genetic research, in Latin America, particularly Brazil. [...] At one time, when I was quite enthusiastic about it, I thought that really was a great success. I felt myself a part of the biological research scene in Brazil. They gave me an honorary doctorate. In recent years, I had a disillusion along these lines. I'm afraid it has to be said, it was a bitter disillusion, which came as a result of most of my friends in Brazil, with some fortunate exceptions, having abandoned the work. Some of these people out there are intellectually, culturally, the equals of anybody anywhere." (pp. 525-526)

He continued talking about Brazil for the next 40 pages, to finish with a deep bitter statement:

"A school of genetics appeared in Brazil, a school which did not exist before, and it is a real disappointment to me that this school did not develop, later, after Dreyfus's death, as well as it might have developed.“ (p. 548)

I see this as unfair, and probably motivated by disagreements he later had with Crodowaldo Pavan and also due to the bad results obtained in his last visit to Brazil in 1955 (an analysis of this episode is made in Moscoso, 1992). It is relevant here to stress that in 1950 Pavan discovered an exceptionally favorable organism to work with: the fly Rhynchosciara angelae, which had polytene chromosomes even larger as those of Drosophila. Pavan totally redirected his research toward this organism in 1960; the success in doing this resulted in an invitation to create a laboratory for studying Rhynchosciara at the Oak Ridge National Laboratory and sooner afterwards at The University of Texas (Brito da Cunha, 1989). It can also be said that other disciples from the beginning years with Drosophila were moving to other organisms; that was the case of Newton Freire-Maia and Oswaldo Frota Pessoa, who went to human genetics. Moreover, the former had an earlier disagreement with Dobzhansky, since he was interested in studying a species that was not a Dobzhansky's favorite: Drosophila kikkawai. Other young Brazilian geneticists not belonging to the "first generation" who started to work with Drosophila changed interests, as for instance Warwick E. Kerr (who moved to bees) and Francisco M. Salzano (human genetics). It is possible that all these events had contributed to a sort of "disillusionment" in Dobzhansky's expectations. Additionally, genetics in Brazil flourished and diversified in the fifties and sixties attaining an international reputation. The Brazilian Society of Genetics was founded in 1955 by 22 members. In 1960, when the first historical account was made on the development of genetics in Brazil, it had 160 associates, and by 1978 when the Brazilian Journal of Genetics (presently called Genetics and Molecular Biology) was launched, it had more than 1100 associates, making it one of the largest scientific societies in Latin America. On the other hand, while it is true that Dobzhansky greatly influenced the development of genetics and evolution in Brazil, genetics in this country was already an active field of research by the early forties: what Dobzhansky called "a school of genetics" was in fact an overdevelopment of the Drosophila work strongly supported by the Rockefeller Foundation. Plant genetics, for instance, developed independently and attained a very respectable position on the international scene. The same can be said of human genetics, which started to grow in the 
1960s becoming a general reference for studies in medical genetics and the evolution of Amerindian populations.

\section{Acknowledgments}

I would like to express my deep thanks to Francisco Mauro Salzano for his critical comments on a first draft of this paper as well as for his help with some important bibliographic references. William B. Provine suggested the topic a few years ago, provided many important references and copies of documents, and was of great help and kindness on many occasions during my stay at Cornell University; to him I am also greatly indebted. Two anonymous referees made important criticisms and were greatly helpful to call my attention to some parts of the text.

\section{References}

Araújo AM (1998) A influência de Theodosius Dobzhansky no desenvolvimento da Genética no Brasil. Episteme 3(7):4354.

Araújo AM (2001) O salto qualitativo em Theodosius Dobzhansky: Unindo as tradições naturalista e experimentalista. História, Ciências, Saúde 8:713-726.

Beiguelman B (1980) A Genética Humana no Brasil. In: Ferri MG and Motoyama S (eds) História das Ciências no Brasil. Edit. Pedagógica e Universitária, São Paulo. pp 273-306.

Brieger FG (1944) Considerações sobre o mecanismo da evolução. Anais Esc. Sup. Agric. "Luiz de Queiroz" 1:177-203.

Brito da Cunha A (1989) The seventy years of life of C. Pavan and science. Rev. Bras. Genética 12:691-705.

Condurú JMH (1934) ABC da Genética. v. 1. Livraria Pará, Belém.

Dobzhansky T (1937) Genetics and the Origin of Species. The Columbia Classics in Evolutionary Series. Columbia Univ. Press, New York, 364 pp.

Dobzhansky T (1951) Genetics and the Origin of Species. 3rd edition. Columbia Univ. Press, New York, 364 pp.

Dobzhansky T (1962) Oral History Memoir. Columbia University, Oral History Research Office, New York, 639 pp.

Dobzhansky T (1970) Genetics of the Evolutionary Process. Columbia Univ. Press, New York, 505 pp.

Dreyfus A (1934) Vida e Universo e Outros Ensaios. Comp. Edit. Nacional, São Paulo, 196 pp.

Ferri MG (1980) História da Botânica no Brasil. In: Ferri MG and Motoyama S (eds). História das Ciências no Brasil. Edit. Pedagógica e Universitária, São Paulo, pp 33-88.

Fisher RA (1918) The correlation between relatives on the supposition of Mendelian inheritance. Royal Soc (Edinburgh) Trans 52:399-433.

Fisher RA (1922) On the dominance ratio. Roy Soc Edin Proc 42:321-341.

Fisher RA (1930) The Genetical Theory of Natural Selection. Clarendon Press. Oxford, 291 pp (reprinted by Dover Editions, 1958).

Glick T (1994) The Rockefeller Foundation and the emergence of Genetics in Brazil, 1943-1960. In: Cueto M (ed) Missionaries of Science - The Rockefeller Foundation in Latin America, Indiana Univ. Press. pp 149-164.
Haldane JBS (1924a) A mathematical theory of natural and artificial selection. Part I. Cambridge Phil Soc Trans 23:19-41.

Haldane JBS (1924b) A mathematical theory of natural and artificial selection. Part II. Cambridge Phil Soc Proc Biology 1:158-163.

Haldane JBS (1926) A mathematical theory of natural and artificial selection. Part III. Cambridge Phil Soc Proc 23:363372 .

Haldane JBS (1932) The Causes of Evolution. Cornell Univ. Press, Ithaca, $235 \mathrm{pp}$.

Krug CA (1932) Sexto Congresso Internacional de Genética. Ithaca, Nova York, 24 a 30 de Agosto de 1932. Revista de Agricultura, Piracicaba 7:446-454

Krug CA (1940) Genética e evolução. Revista de Agricultura, Piracicaba 15:271-288.

Marinho MGSMC (2001) Norte-Americanos no Brasil - Uma História da Fundação Rockefeller na Universidade de São Paulo (1934-1952). Edit Autores Associados, São Paulo, $196 \mathrm{pp}$.

Mayr E (1942) Systematics and the Origin of Species. The Columbia Classics in Evolution Series. Columbia Univ. Press, New York, 334 pp.

Mayr E and Provine WB (eds) (1980) The Evolutionary Synthesis - Perspectives on the Unification of Biology. Harvard Univ. Press, Massachusetts, $487 \mathrm{pp}$.

Mayr E and Provine WB (eds) (1998) The Evolutionary Synthesis - Perspectives on the Unification of Biology. Harvard Univ. Press, Massachusetts, 487 pp (with a new Preface).

Mendes JC (1981) A pesquisa paleontológica no Brasil. In: Ferri MG and Motoyama S (eds) História das Ciências no Brasil. Editora Pedagógica e Universitária, São Paulo, pp 43-72.

Moscoso T (1992) Genetics and geneticists in Brazil: An essay about Latin American science and scientists. Thesis, Bach. of Arts. Harvard Univ, 88 pp.

Narchi W (1980) A Zoologia no Brasil. In: Ferri MG and Motoyama S (eds) História das Ciências no Brasil. Editora Pedagógica e Universitária, São Paulo, pp 89-116.

Pavan C and Brito da Cunha A (2003) Theodosius Dobzhansky and the development of Genetics in Brazil. Genetics and Molecular Biology, 26:387-395.

Pavan C and Brito da Cunha A (unp. manuscript) Dobzhansky's role on Genetics in São Paulo.

Provine WB (1986) Sewall Wright and Evolutionary Biology. The Univ. of Chicago Press, Chicago, 545 pp.

Provine WB (unp. manuscript) - Theodosius Dobzhansky - Quantitative Theory and Field Research. (a brief summary of remarks prepared for the International Dobzhansky Symposium, Leningrad 17-19 September 1990).

Reif W, Junker T and Hossfeld U (2000) The synthetic theory of evolution: General problems and the German contribution to the synthesis. Theory Bioscience, 119:41-91.

Schwartzman S (1979) Formação da Comunidade Científica no Brasil. Companhia Edit. Nacional. FINEP, Rio de Janeiro, $481 \mathrm{pp}$.

Simpson GG (1944) Tempo and Mode in Evolution. Columbia Univ. Press, New York, 237 pp.

Smocovitis VB (1992) Unifying biology: The evolutionary synthesis and evolutionary biology. Journal of the History of Biology 25:1-65. 
Smocovitis VB (1996) Unifying Biology: The Evolutionary Synthesis and Evolutionary Biology. Princeton University Press, New Jersey, 230 pp.

Stebbins GL (1950) Variation and Evolution in Plants. Columbia Univ. Press, New York, 543 pp.

Toledo Piza Jr S (1930) Localização dos Factores na Linina Nuclear como Base de uma Nova Teoria sobre a Hereditariedade. Esc. Superior de Agricultura "Luiz de Queiroz", Piracicaba. (apud Glick, 1994).

Vaz Z (1966) André Dreyfus. In: Pavan C and Brito da Cunha A (eds) Elementos de Genética, Companhia Editora Nacional, pp 1-17.
Wright S (1929) Evolution in a Mendelian population. Anatomical Record 44:287.

Wright S (1931) Evolution in Mendelian populations. Genetics 16:97-159.

Wright S (1932) The roles of mutation, inbreeding, crossbreeding and selection in evolution. Proc Sixth Intern Congress of Genetics 1:356-366.

Wright S and Provine WB (eds) (1986) Evolution - Selected Papers. The University of Chicago Press. Chicago, 649 pp.

EditorAssociado: Louis Bernard Klaczko 